\title{
PENATAAN ORGANISASI PUSAT PENGEMBANGAN SUMBER DAYA MANUSIA APARATUR MELALUI REVISI PERATURAN MENTERI ESDM NO. 13 TAHUN 2016
}

\author{
Fahmi Aulia Rakhman ${ }^{1)}$, Dian Anggarini' \\ Pusat Pengembangan Sumber Daya Manusia Aparatur \\ Email : fahmi.rakhman@esdm.go.id \\ Pusat Pengembangan Sumber Daya Manusia Aparatur \\ Email : dian.anggarini@esdm.go.id
}

\begin{abstract}
ABSTRAK
Penelitian ini difokuskan untuk mendeskripsikan perlunya reorganisasi di Pusat Pengembangan Sumber Daya Manusia Aparatur (PPSDMA) dikarenakan perlunya simplifikasi dan sinkronisasi antar kegiatan. Metode yang digunakan dalam penelitian ini yaitu metode kualitatif. Penelitian ini diajukan untuk menganalisis dan mengungkapkan ketidakefektifan dalam fungsi organisasi dan adanya tumpang tindih kewenangan di organisasi Pusat Pengembangan Sumber Daya Manusia Aparatur. Hasil dari penulisan ini menggambarkan adanya perubahan signifikan dari tugas dan fungsi bidang di PPSDMA berdasarkan Peraturan Menteri ESDM Nomor 13 Tahun 2016 berbanding dengan usulan reorganisasi.
\end{abstract}

Kata Kunci : penataan, organisasi, reorganisasi

\begin{abstract}
This research is focused on describing the need for reorganization in the Human Resources Development Center for Government Apparatus (PPSDMA) due to the need for simplification and synchronization between activities. The method used in this study is a qualitative method. This research was proposed to analyze and reveal the ineffectiveness in organizational functions and the overlapping authority in the organization of the the Human Resources Development Center for Government Apparatus (PPSDMA). The results of this paper illustrate that there are significant changes in the duties and functions of the field in PPSDMA based on the Minister of Energy and Mineral Resources Regulation No. 13 of 2016 compared to the proposed reorganization.
\end{abstract}

Keyword: adjustment, organization, reorganization

\section{PENDAHULUAN}

Perubahan jumlah unit dan struktur organisasi bukan merupakan permasalahan yang sederhana bagi sebuah organisasi. Perubahan tersebut memberi efek yang besar terhadap berbagai dimensi kelembagaan Pemerintah. Beberapa konsep yang terkait dengan reorganisasi adalah merger, akuisisi, revitalisasi, dan restrukturisasi. Implementasi restrukturisasi organisasi memberikan efek pada dimensi-dimensi utama dalam organisasi, yaitu: manajemen sumber daya manusia, perubahan manajemen keuangan, perubahan struktur organisasi, perubahan manajemen (tatalaksana organisasi), penguatan budaya organisasi, dan kualitas pelayanan publik.

Berdasarkan survei yang dilakukan oleh Transparansi Internasional terhadap persepsi pelaku bisnis atas korupsi di suatu negara, Indeks Persepsi Korupsi di Indonesia menunjukan bahwa korupsi di Indonesia masih sangat tinggi, nilai Indonesia masih dibawah angka 3 dengan interval angka 0 sampai dengan 10 , yaitu angka 0 menunjukan tingkat korupsi sangat tinggi atau terkorup sedangkan angka 10 menunjukan negara yang bersih dari korupsi.Birokrat terhadap masyarakat justru bersikap sebagai tuan yang harus dilayani oleh masyarakat. Birokat menjadi tidak responsif akan kebutuhan masyarakat dan lambat dalam mengambil sikap atas perubahan yang terjadi. Pada sisi lain, birokrasi tumbuh sebagai kekuatan tersendiri yang terpisah dari masyarakat. Birokrasi yang direpresentasikan dengan aparatur negaranya baik pejabat negara dan pegawai negeri sipil telah mengerogoti sendisendi negara dengan maraknya praktek korupsi yang sampai saat ini menjadi penyakit yang sulit disembuhkan.

Sumber Daya Manusia Aparatur pada Pusat Pengembangan Sumber Daya Manusia Aparatur (PPSDMA) dihadapkan pada 2 (dua) masalah utama, yaitu kualitas dan distribusi (penempatan). Kualitas Sumber Daya Aparatur masih merupakan 
permasalahan serius jika dikaitkan dengan kinerja. Implikasi yang paling mudah diidentifikasi adalah efek reorganisasi terhadap struktur organisasi. Reorganisasi dapat berpengaruh terhadap struktur, yaitu semakin besar atau semakin ramping. Organisasi pemerintah secara umum dibentuk dengan struktur yang besar sehingga dipandang tidak efisien dan tidak ekonomis. Dimensi lain dari implikasi reorganisasi yang perlu mendapat perhatian dengan cermat adalah tatalaksana (manajemen) organisasi. PPSDMA masih mempunyai permasalahan mendasar dalam pelaksanaan fungsi-fungsi manajemen. Simplifikasi dan sinkronisasi kegiatan masih sering mengalami kendala dengan kuatnya kepentingan antar unit atau bidang.

Permasalahan yang akan dibahas dalam penulisan ini yaitu:

1. Apa saja perubahan tugas Bidang/Bagian dalam usulan re-organisasi ini?

2. Bagaimanakah PPSDMA menghadapi adanya fungsi Asessment, dan bagaimanakah pengaturan mengenai Asessment Center?

Berdasarkan permasalahan diatas,penelitian terhadap reorganisasi Pusat Pengembangan Sumber Daya Manusia Aparatur (PPSDMA) merupakan suatu hal yang menarik untuk dibahas dalam rangka pemberdayaan organisasi.

\section{TINJAUAN TEORI}

\section{Birokrasi Pemerintah}

Pengertian Birokrasi Pemerintah menurut Rod Hague dkk adalah institusi pemerintahan yang melaksanakan tugas negara. "The bureaucracy is the institution that carries out the function and responsibilities of the state. It is the engine-room of the state. Sedangkan Max Weber memandang birokrasi sebagai sistem adminsitrasi rutin yang dilakukan dengan keseragaman, diselenggarakan dengan cara-cara tertentu didasarkan aturan tertulis, oleh orang-orang yang berkompeten dibidangnya.

\section{Organisasi}

Organisasi dapat dipahami dari berbagai macam sudut pandang atau perspektif ${ }^{2}$ yaitu sebagai kesatuan rasional dalam upaya untuk mengejar tujuan sebagai koalisi pendukung yang kuat dimana organisasi merupakan instrumen untuk mengejar kepentingan masing-masing, sebagai suatu sistem terbuka dimana kelang- sungan hidup organisasi sangat tergantung input dan lingkungan, sebagai alat dominasi dan banyak lagi pesrpektif yang dapat dipakai untuk memaknai organisasi. Jika diuraikan secara lebih terperinci setiap organisasi pasti memiliki berbagai dimensi penting sebagai ciri dari suatu organisasi, yaitu ${ }^{3}$ :

a. Wadah atau struktur yang menjadi kerangka orang-orang yang menjadi bagian dari organisasi tersebut melakukan aktivitasnya;

b. Anggota yang menjadi bagian dari organisasi;

c. Interaksi yang terpolakan dengan mekanisme tertentu sehingga terjadi koordinasi yang baik antara satu orang atau bagian dengan orang atau bagian yang lain; dan

d. Tujuan bersama yang ingin diwujudkan oleh orang-orang yang menjadi bagian dari organisasi tadi.

\section{Perubahan Organisasi}

Perubahan organisasi merupakan hasil dari pembuatan keputusan organisasi. Pimpinan mengevaluasi kondisi saat ini, lalu memutuskan arah kemana masa depan yang diinginkan organisasi, selanjutnya mengelola proses perubahan yang diinginkan. Untuk itu terdapat 3 (tiga) langkah perubahan organisasi yaitu, pertama, menentukan perlunya perubahan, kedua, identifikasi hambatan perubahan, dan ketiga, menentukan strategi perubahan.

\section{Kekuatan Perubahan Greenberg dan Baron}

Greenberg dan Baron berpendapat bahwa terdapat beberapa faktor yang menupakan kekuatan di belakang kebutuhan akan perubahan. Mereka memisahkan antara perubahan terencana dan perubahan tidak terencana. Perubahan terencana adalah aktivitas yang dimaksudkan dan diarahkan dalam sifat dan desainnya untuk memenuhi beberapa tujuan organisasi, sementara perubahan tidak terencana merupakan pergeseran dalam aktivitas organisasi karena adanya kekuatan yang bersifat eksternal diluar kontrol organisasi.

\section{a. Perubahan terencana}

Kekuatan dalam perubahan terencana adalah sebagai berikut:

1) Perubahan dalam ukuran dan struktur organsasi;

2) Perubahan dalam sistem administrasi;

${ }^{1}$ M. Mas'ud Said, Birokrasi di Negara Birokratis : Makna, Masalah, dan Dekonstruksi Birokrasi Indonesia, (Malang: UMM Press, 2009), h. 55

${ }^{2}$ W. Richard Scoot, Organization, Rational, Natural, and Open Systems, dalam Miftah Thoha, Birokrasi Pemerintah Indonesia di Era Reformasi *Cet-2; jakarta : Kencana, 2008), h. 35

Abdulsyani, Drs, Manajemen Organisasi, (Jakarta, PT. Bina Aksara, 1987), h. 24 
3) Adanya pengenalan teknologibaru.

\section{b. Perubahan tidak terencana}

Perubahan ini terjadi karena:

1) Pergeseran demografis pekerja;

2) Kesenjangan kinerja;

3) Peraturan Pemerintah;

4) Kompetisi global;

5) Perubahan kondisi ekonomi;

6) Kemajuan teknologi.

Greenberg dan Baron mengidentifikasikan adanya 5 (lima) faktor yang menjadi hambatan individual untuk perubahan ${ }^{5}$ :

a. Economic Insecurity (Ketidakamanan Ekonomis)

Perubahan memiliki potensi bagi seseorang untuk kehilangan pekerjaan atau terkena penurunan upah, jadi perubahan dapat menimbulkan ketidakamanan secara ekonomis kepada karyawan sehingga mengakibatkan menjadi resisten atau menolak terhadap perubahan.

b. Fear of the Unknown (Ketakutan atas Hal yang Tidak Diketahui)

Perubahan merupakan gangguan terhadap suatu situasi yang sudah mapan, sehingga karyawan sering menolak perubahan karena takut menghadapi konsekuensi dari perubahan tersebut.

c. Threats to Social Relationship (Ancaman terhadap Hubungan Sosial)

Suatu perubahan dapat merusak tatanan hubungan sosial yang tidak diinginkan. Kekhawatiran tersebut menyebabkan sebagian diantara kita tetap ingin mempertahankan status quo.

d. Habits (Kebiasaan)

Perubahan dalam cara mengerjakan pekerjaan sering berakibat pada keharusan untuk mengubah kebiasan yang menimbulkan ketidaknyamanan.

e. Failure to Recognize Need for Change (Kegagalan Mengenal Kebutuhan untuk Berubah)

Terjadi resistensi karena kurang paham atas kebutuhan perubahan.

\section{METODE PENELITIAN}

Dalam menjelaskan permasalahan, digunakan pendekatan yuridis normatif. Penelitian yuridis normatif adalah penelitian yang mengacu kepada norma-norma hukum yang terdapat dalam perundang-undangan, peraturan-peraturan, dan kebijakan-kebijakan pemerintah. Dalam penelitian hukum normatif ini, yang diteliti adalah bahan pustaka atau data sekunder yang mencakup bahan hukum primer dan bahan hukum sekunder. Data primer diperoleh melalui wawancara mendalam (in-depth interview) terhadap narasumber, sedangkan data sekunder diperoleh dari studi kepustakaan.

Wawancara mendalam telah dilakukan terhadap pihak-pihak terkait yang mengetahui proses reorganisasi PPDMA, yaitu bidang Pengembangan Kompetensi, yaitu Kepala Sub Bidang Perencanaan Pengembangan Kompetensi dan Kepala Sub Bidang Pelaksanaan Pengembangan Kompetensi, dan Bagian Tata Usaha yaitu Kepala Sub Bagian Kepegawaian dan Umum, serta Staf Sub Bagian Kepegawaian dan Umum yang menangani organisasi dan tata laksana.

\section{PEMBAHASAN}

Pusat Pengembangan Sumber Daya Manusia Aparatur (PPSDMA) memiliki pegawai sebanyak 77 (tujuh puluh tujuh) orang, dijabarkan dibawah ini dengan perincian berdasarkan Jabatan dan Pendidikan sebagai berikut:

Tabel 1. Pegawai PPSDM Aparatur Berdasarkan Jabatan

\begin{tabular}{|c|l|c|}
\hline No & \multicolumn{1}{|c|}{ Jabatan } & Jumlah \\
\hline 1 & Pejabat Eselon II & 1 \\
\hline 2 & Pejabat Eselon III & 4 \\
\hline 3 & Pejabat Eselon IV & 8 \\
\hline 4 & Widyaiswara & 13 \\
\hline 5 & Pranata Komputer & 2 \\
\hline 6 & Arsiparis & 3 \\
\hline 7 & Pustakawan & 1 \\
\hline 8 & Pranata Humas & 1 \\
\hline 9 & Analis Kepegawaian & 1 \\
\hline 10 & Asessor SDM Aparatur & 2 \\
\hline 11 & Fungsional Umum & 41 \\
\hline
\end{tabular}


Tabel 2. Pegawai PPSDM Aparatur Berdasarkan Jenis Keilmuan

\begin{tabular}{|c|l|c|}
\hline No & \multicolumn{1}{|c|}{ Jabatan } & Jumlah \\
\hline 1 & Sarjana Teknis & 11 \\
\hline 2 & Sarjana Non Teknis & 19 \\
\hline 3 & Pasca Sarjana Teknis & 12 \\
\hline 4 & Pasca Sarjana Non Teknis & 10 \\
\hline 5 & Non Sarjana & 25 \\
\hline
\end{tabular}

Tabel 3. Pegawai PPSDM Aparatur Berdasarkan Pendidikan

\begin{tabular}{|c|l|c|}
\hline No & \multicolumn{1}{|c|}{ Jabatan } & Jumlah \\
\hline 1 & Pasca Sarjana & 22 \\
\hline 2 & Sarjana & 30 \\
\hline 3 & Sarjana Muda & 2 \\
\hline 4 & Setingkat SLTA & 21 \\
\hline 5 & Setingkat SLTP & 1 \\
\hline 6 & Sekolah Dasar & 1 \\
\hline
\end{tabular}

Gambar 3. Pegawai PPSDMA berdasarkan Pendidikan

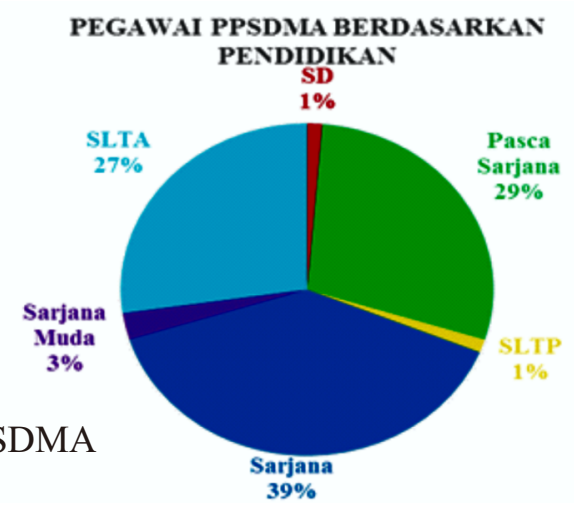

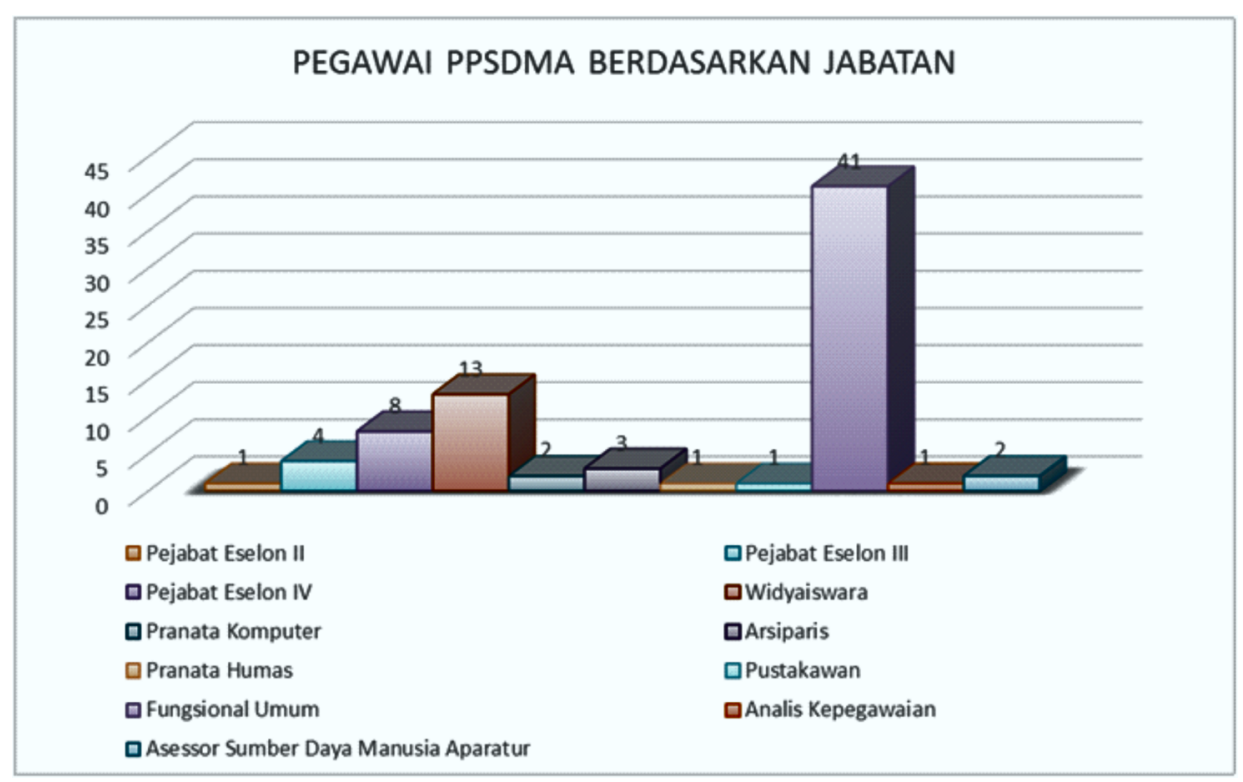

Gambar 1. Pegawai PPSDMA berdasarkan Jabatan 
A. Struktur dan Fungsi Organisasi Saat ini

STRUKTUR ORGANISASI

PUSAT PENGEMBANGAN SUMBER DAYA MANUSIA APARATUR

BADAN PENGEMBANGAN SUMBER DAYA MANUSIA ENERGI DAN SUMBER DAYA MINERAL

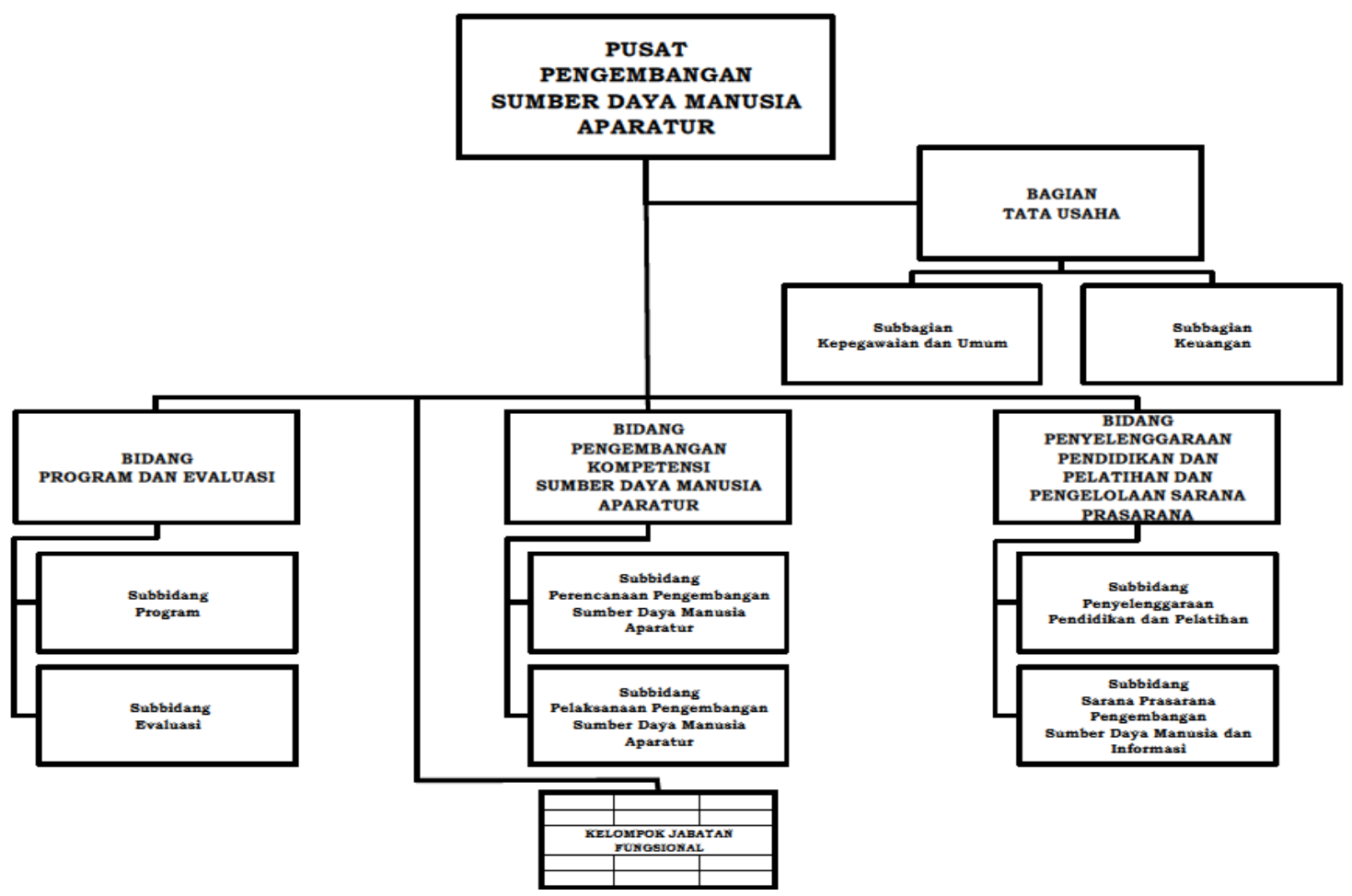

Gambar 4. Struktur Organisasi PPSDMA Saat ini

PETA PROSES BISNIS UTAMA PPSDMA SAAT INI

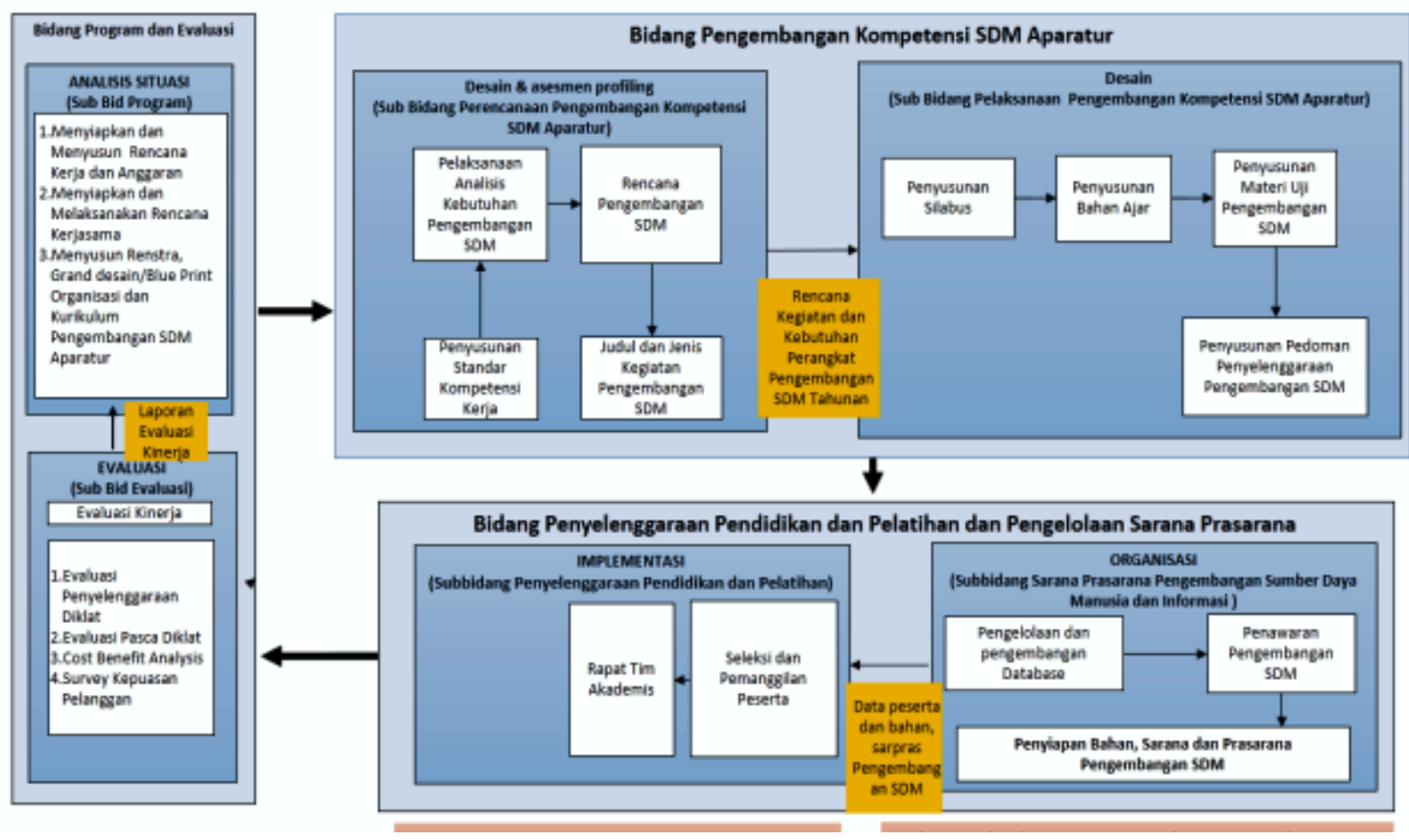

Gambar 5. Peta Proses Bisnis Utama PPSDMA Saat ini 
Pusat Pengembangan Sumber Daya Manusia Aparatur menyelenggarakan fungsi:

a. Penyiapan penyusunan kebijakan teknis Pengembangan Sumber Daya Manusia Aparatur di bidang kepemimpinan, manajemen, dan administrasi;

b. Penyusunan program, akuntabilitas kinerja dan evaluasi serta pengembangan sumber daya manusia di bidang kepemimpinan, manajemen, dan administrasi;

c. Penyiapan bahan penyusunan perencanaan pengembangan sumber daya manusia, pengelolaan penyertaan pendidikan dan pelatihan, magang, seminar, lokakarya, tugas belajar dan izin belajar, analisis standar kompetensi jabatan, serta analisis kompetensi pengembangan sumber daya manusia di bidang kepemimpinan, manajemen, dan administrasi;

d. Pelaksanaan penyelenggaraan pendidikan dan pelatihan di bidang kepemimpinan, manajemen, dan administrasi;

e. Pelaksanaan pengelolaan sarana prasarana dan informasi pengembangan sumber daya manusia di bidang kepemimpinan, manajemen, dan administrasi;

f. Pemantauan, evaluasi dan pelaporan pelaksanaan tugas di bidang pengembangan sumber daya manusia di bidang kepemimpinan, manajemen, dan administrasi; dan

g. Pelaksanaan administrasi Pusat Pengembangan Sumber Daya Manusia di bidang kepemimpinan, manajemen, dan administrasi.

Pusat Pengembangan Sumber Daya Manusia Aparatur terdiri atas:

a. Bagian Tata Usaha;

b. Bidang Program dan Evaluasi;

c. Bidang Pengembangan Kompetensi Sumber Daya Manusia Aparatur; dan

d. Bidang Penyelenggaraan Pendidikan dan Pelatihan dan Pengelolaan Sarana Prasarana.

Bagian Tata Usaha mempunyai tugas melaksanakan urusan kepegawaian, kerumahtanggaan, ketatausahaan, dan keuangan Pusat Pengembangan Sumber Daya Manusia Aparatur. fungsi:

Bagian Tata Usaha menyelenggarakan

a. Pelaksanaan urusan ketatausahan, perlengkapan, kerumahtanggaan, kepegawaian, organisasi, tata laksana, pelaksanaan manajemen perubahan, hukum, hubungan masyarakat, serta keprotokolan; dan

b. Pelaksanaan urusan keuangan dan administrasi barang milik negara.

Bagian Tata Usaha terdiri atas:

a. Subbagian Kepegawaian dan Umum mem- punyai tugas melakukan urusan ketatausahaan, kearsipan, perlengkapan, kerumahtanggaan, kepegawaian, organisasi, tata laksana, pelaksanaan manajemen perubahan, hukum, hubungan masyarakat, serta keprotokolan.

b. Subbagian Keuangan mempunyai tugas melakukan urusan keuangan dan administrasi barang milik negara.

Bidang Program dan Evaluasi mempunyai tugas melaksanakan penyiapan bahan penyusunan pengelolaan rencana, program, anggaran, pelaporan, pelaksanaan kerja sama, evaluasi dan akuntabilitas kinerja di bidang pengembangan sumber daya manusia bidang kepemimpinan, manajemen, dan administrasi.

Bidang Program dan Evaluasi menyelenggarakan fungsi:

a. Penyiapan bahan penyusunan pengelolaan rencana,program, anggaran, pelaporan, dan pelaksanaan kerja sama di bidang pengembangan sumber daya manusia bidang kepemimpinan, manajemen, dan administrasi; dan

b. Penyiapan bahan evaluasi dan akuntabilitas kinerja di bidang pengembangan sumber daya di bidang pengembangan sumber daya manusia bidang kepemimpinan, manajemen, dan administrasi.

Bidang Program dan Evaluasi terdiri atas:

a. Subbidang Program; dan

b. Subbidang Evaluasi.

1) Subbidang Program mempunyai tugas melakukan penyiapan bahan penyusunan pengelolaan rencana, program, anggaran, pelaporan, dan pelaksanaan kerja sama di bidang pengembangan sumber daya manusia bidang kepemimpinan, manajemen, dan administrasi.

2) Subbidang Evaluasi mempunyai tugas melakukan penyiapan bahan evaluasi dan akuntabilitas kinerja di bidang pengembangan sumber daya manusia bidang kepemimpinan, manajemen, dan administrasi.

Bidang Pengembangan Kompetensi Sumber Daya Manusia Aparatur mempunyai tugas melaksanakan penyiapan kebijakan teknis, penyusunan perencanaan pengembangan sumber daya manusia, pengelolaan penyertaan pendidikan dan pelatihan, magang, seminar, lokakarya, tugas belajar dan izin belajar di bidang pengembangan sumber daya manusia aparatur bidang kepemimpinan, manajemen, dan administrasi.

Bidang Pengembangan Kompetensi Sumber Daya Manusia Aparatur menyelenggarakan fungsi:

a. Penyiapan bahan penyusunan perencanaan; 
b. Pengembangan sumber daya manusia aparatur bidang kepemimpinan, manajemen, dan administrasi, pengelolaan penyertaan pendidikan dan pelatihan, magang, seminar, lokakarya, tugas belajar, dan izin belajar; dan

c. Penyiapan bahan pelaksanaan pengembangan sumber daya manusia aparatur di bidang kompetensi pengembangan sumber daya manusia bidang kepemimpinan, manajemen, dan administrasi.

Bidang Pengembangan Kompetensi Sumber Daya Manusia Aparatur terdiri atas:

a. Subbidang Perencanaan Pengembangan Sumber Daya Manusia Aparatur; dan mempunyai tugas melaksanakan penyiapan bahan penyusunan perencanaan pengembangan sumber daya manusia aparatur bidang kepemimpinan, manajemen, dan administrasi, pengelolaan penyertaan pendidikan dan pelatihan, magang, seminar, lokakarya, tugas belajar, dan izin belajar

b. Subbidang Pelaksanaan Pengembangan Sumber Daya Manusia Aparatur mempunyai tugas melakukan penyiapan bahan pelaksanaan pengembangan sumber daya manusia aparatur di bidang kompetensi pengembangan sumber daya manusia bidang kepemimpinan, manajemen, dan administrasi.

Bidang Penyelenggaraan Pendidikan dan Pelatihan dan Pengelolaan Sarana Prasarana mempunyai tugas penyelenggaraan dan pemantauan pendidikan dan pelatihan serta pengelolaan sarana prasarana dan informasi, pengembangan sumber daya manusia dan Informasi di bidang kepemimpinan, manajemen, dan administrasi.

Bidang Penyelenggaraan Pendidikan dan
Pelatihan dan Pengelolaan Sarana Prasarana menyelenggarakan fungsi:

a. Penyiapan pelaksanaan penyelenggaraan pendidikan dan pelatihan di bidang kepemimpinan, manajemen, dan administrasi; dan

b. Penyiapan pelaksanaan pengelolaan sarana prasarana dan informasi pengembangan sumber daya manusia di bidang kepemimpinan, manajemen, dan administrasi.

Bidang Penyelenggaraan Pendidikan dan Pelatihan dan Pengelolaan Sarana Prasarana terdiri atas :

a. Subbidang Penyelenggaraan Pendidikan dan Pelatihan mempunyai tugas melakukan penyiapan pelaksanaan penyelenggaraan pendidikan dan pelatihan di bidang kepemimpinan, manajemen, dan administrasi.

b. Subbidang Sarana Prasarana Pengembangan Sumber Daya Manusia dan Informasi mempunyai tugas melakukan penyiapan pelaksanaan pengelolaan sarana prasarana dan informasi pengembangan sumber daya manusia di bidang kepemimpinan, manajemen, dan administrasi.

\section{B. Perbandingan Fungsi Organisasi dan Usulan Perubahan}

Pengembangan atau perubahan organisasi merupakan suatu tuntutan yang senatiasa harus dilakukan secara sistematis. PPSDMA mengajukan perubahan fungsi dari beberapa bidang dan sub bidang sebagai upaya evaluasi terus menerus untuk perbaikan organisasi.

Berikut perubahan yang diusulkan oleh PPSDMA:

\section{SEMULA \\ Pasal 931}

Pusat Pengembangan Sumber Daya Manusia Aparatur mempunyai tugas melaksanakan Pengembangan Sumber Daya Manusia Aparatur di bidang kepemimpinan, manajemen, dan administrasi.

\section{Pasal 932}

Dalam melaksanakan tugas sebagaimana dimaksud dalam Pasal 931, Pusat Pengembangan Sumber Daya Manusia Aparatur menyelenggarakan fungsi:

a. penyiapan penyusunan kebijakan teknis Pengembangan Sumber Daya Manusia Aparatur di bidang kepemimpinan, manajemen, dan administrasi;

b. penyusunan program, akuntabilitas kinerja dan evaluasi serta pengembangan sumber daya manusia di bidang kepemimpinan, manajemen, dan administrasi;

c. penyiapan bahan penyusunan perencanaan pengembangan sumber daya manusia, pengelolaan penyertaan pendidikan dan pelatihan, magang, seminar, lokakarya, tugas belajar dan izin belajar, analisis standar kompetensi jabatan, serta analisis

\section{MENJADI}

Pasal 931

Pusat Pengembangan Sumber Daya Manusia Aparatur mempunyai tugas melaksanakan pengembangan kompetensi sumber daya manusia aparatur di bidang kepemimpinan, manajemen, dan administrasi.

\section{Pasal 932}

Dalam melaksanakan tugas sebagaimana dimaksud dalam Pasal 931, Pusat Pengembangan Sumber Daya Manusia Aparatur menyelenggarakan fungsi:

a. penyiapan penyusunan kebijakan teknis pengembangan kompetensi sumber daya manusia aparaturdi bidang kepemimpinan, manajemen, dan administrasi;

b. penyusunan program, akuntabilitas kinerja, dan evaluasi serta pengembangan kompetensi sumber daya manusia di bidang kepemimpinan, manajemen, dan administrasi;

c. penyiapan bahan pengelolaan penyertaan pendidikan dan pelatihan, serta analisis kompetensi pengembangan sumber daya manusia di bidang kepemimpinan, manajemen, dan administrasi; 


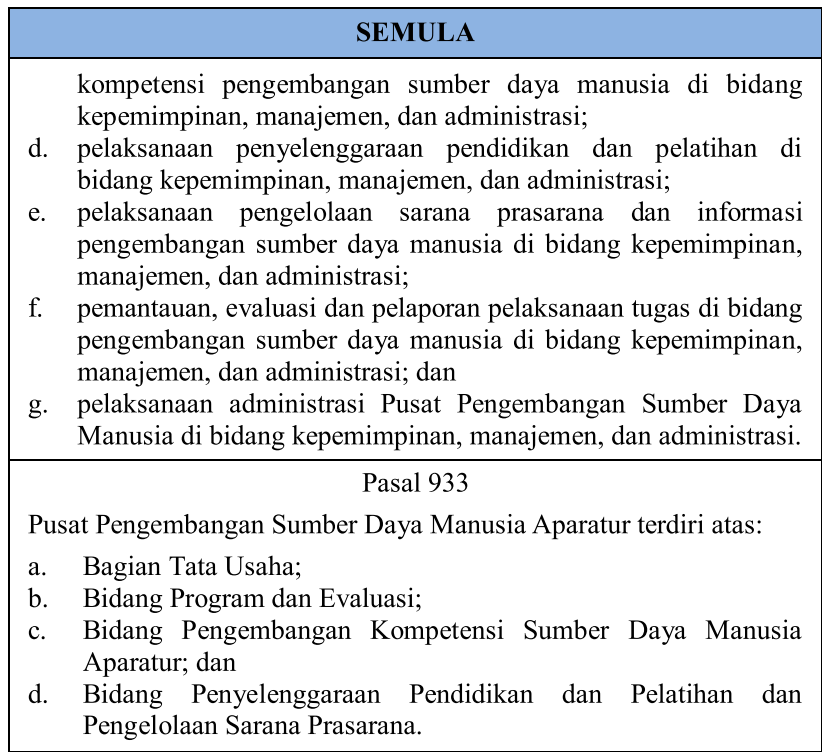

\section{MENJADI}

d. pelaksanaan penyelenggaraan pengembangan kompetensi sumber daya manusiadan pengelolaan sistem informasi pengembangan kompetensi sumber daya manusia di bidang kepemimpinan, manajemen, dan administrasi;

e. penyiapan standar dan pelaksanaan penilaian kompetensi aparatur;

f. pemantauan, evaluasi pelaporan pelaksanaan tugas pengembangan kompetensisumber daya manusia di bidang kepemimpinan, manajemen, dan administrasi; dan

g. pelaksanaan administrasi pusat pengembangan sumber daya manusia di bidang kepemimpinan, manajemen, dan administrasi.

Pusat Pengembangan Sumber Daya Manusia Aparatur terdiri atas:

a. Bagian Tata Usaha;

b. Bidang Program dan Evaluasi;

c. Bidang Penilaian Kompetensi Aparatur; dan

d. Bidang Penyelenggaraan Pengembangan Kompetensi Aparatur.

\section{Pasal 934}

Bagian Tata Usaha mempunyai tugas melaksanakan urusan kepegawaian, kerumahtanggaan, ketatausahaan, dan keuangan Pusat Pengembangan Sumber Daya Manusia Aparatur.

$$
\text { Pasal } 935
$$

Dalam melaksanakan tugas sebagaimana dimaksud dalam Pasal 934, Bagian Tata Usaha Nmenyelenggarakan fungsi:

a. pelaksanaan urusan ketatausahan, perlengkapan, kerumahtanggaan, kepegawaian, organisasi, tata laksana, pelaksanaan manajemen perubahan, hukum, hubungan masyarakat, serta keprotokolan; dan

b. pelaksanaan urusan keuangan dan administrasi barang milik negara.

$$
\text { Pasal } 936
$$

Bagian Tata Usaha terdiri atas:

a. Subbagian Kepegawaian dan Umum; dan

b. Subbagian Keuangan

$$
\text { Pasal } 937
$$

(1) Subbagian Kepegawaian dan Umum mempunyai tugas melakukan urusan ketatausahaan, kearsipan, perlengkapan, kerumahtanggaan, kepegawaian, organisasi, tata laksana, pelaksanaan manajemen perubahan, hukum, hubungan masyarakat, serta keprotokolan.

(2) Subbagian Keuangan mempunyai tugas melakukan urusan keuangan dan administrasi barang milik negara.

\section{Pasal 938}

Bidang Program dan Evaluasi mempunyai tugas melaksanakan penyiapan bahan penyusunan pengelolaan rencana, program, anggaran, pelaporan, pelaksanaan kerja sama, evaluasi dan akuntabilitas kinerja di bidang pengembangan sumber daya manusia bidang kepemimpinan, manajemen, dan administrasi.

\section{Pasal 939}

Dalam melaksanakan tugas sebagaimana dimaksud dalam Pasal 938, Bidang Program dan Evaluasi menyelenggarakan fungsi:

a. penyiapan bahan penyusunan pengelolaan rencana, program, anggaran, pelaporan, dan pelaksanaan kerja sama di bidang pengembangan sumber daya manusia di bidang kepemimpinan, manajemen, dan administrasi; dan

b. penyiapan bahan evaluasi dan akuntabilitas kinerja di bidang pengembangan sumber daya di bidang pengembangan sumber daya manusia di bidang kepemimpinan, manajemen, dan administrasi.

\section{Pasal 938}

Bidang Program dan Evaluasi mempunyai tugas melaksanakan penyiapan bahan penyusunan pengelolaan rencana, program, anggaran, pelaporan, pelaksanaan kerja sama, analisis kebutuhan pengembangan kompetensi sumber daya manusia, evaluasi,dan akuntabilitas kinerjapengembangan sumber daya manusia di bidang kepemimpinan, manajemen, dan administrasi.

\section{Pasal 939}

Dalam melaksanakan tugas sebagaimana dimaksud dalam Pasal 938, Bidang Program dan Evaluasi menyelenggarakan fungsi:

a. penyiapan bahan penyusunan pengelolaan rencana, program, anggaran, pelaporan, pelaksanaan kerja sama,dan analisis kebutuhan pengembangan kompetensi sumber daya manusia di bidang kepemimpinan, manajemen, dan administrasi;

b. penyiapan bahan evaluasi dan akuntabilitas kinerja, pengembangan sumber daya di bidang kepemimpinan, manajemen, dan administrasi. 


\begin{tabular}{|c|}
\hline SEMULA \\
\hline Pasal 940 \\
\hline $\begin{array}{l}\text { Bidang Program dan Evaluasi terdiri atas: } \\
\text { a. Subbidang Program; dan } \\
\text { b. Subbidang Evaluasi. }\end{array}$ \\
\hline Pasal 941 \\
\hline $\begin{array}{l}\text { (1) Subbidang Program mempunyai tugas melakukan penyiapan } \\
\text { bahan penyusunan pengelolaan rencana, program, anggaran, } \\
\text { pelaporan, dan pelaksanaan kerja sama di bidang pengembangan } \\
\text { sumber daya manusia bidang kepemimpinan, manajemen, dan } \\
\text { administrasi. } \\
\text { (2) Subbidang Evaluasi mempunyai tugas melakukan penyiapan } \\
\text { bahan evaluasi dan akuntabilitas kinerja di bidang } \\
\text { pengembangan sumber daya manusia bidang kepemimpinan, } \\
\text { manajemen, dan administrasi. }\end{array}$ \\
\hline
\end{tabular}

\section{Pasal 942}

Bidang Pengembangan Kompetensi Sumber Daya Manusia Aparatur mempunyai tugas melaksanakan penyiapan kebijakan teknis, penyusunan perencanaan pengembangan sumber daya manusia, pengelolaan penyertaan pendidikan dan pelatihan, magang, seminar, lokakarya, tugas belajar dan izin belajar di bidang pengembangan sumber daya manusia aparatur bidang kepemimpinan, manajemen dan administrasi.

\section{Pasal 943}

Dalam melaksanakan tugas sebagaimana dimaksud dalam Pasal 942, Bidang Pengembangan Kompetensi Sumber Daya Manusia Aparatur menyelenggarakan fungsi:

a. penyiapan bahan penyusunan perencanaan pengembangan sumber daya manusia aparatur bidang kepemimpinan, manajemen, dan administrasi, pengelolaan penyertaan pendidikan dan pelatihan, magang, seminar, lokakarya, tugas belajar, dan izin belajar; dan

b. penyiapan bahan pelaksanaan pengembangan sumber daya manusia aparatur di bidang kompetensi pengembangan sumber daya manusia bidang kepemimpinan, manajemen, dan administrasi.

\section{Pasal 944}

Bidang Pengembangan Kompetensi Sumber Daya Manusia Aparatur terdiri atas:

a. Subbidang Perencanaan Pengembangan Sumber Daya Manusia Aparatur; dan

b. Subbidang Pelaksanaan Pengembangan Sumber Daya Manusia Aparatur.

\section{Pasal 945}

(1) Subbidang Perencanaan Pengembangan Sumber Daya Manusia Aparatur mempunyai tugas melaksanakan penyiapan bahan penyusunan perencanaan pengembangan sumber daya manusia aparatur bidang kepemimpinan, manajemen, dan administrasi, pengelolaan penyertaan pendidikan dan pelatihan, magang, seminar, lokakarya, tugas belajar, dan izin belajar.

(2) Subbidang Pelaksanaan Pengembangan Sumber Daya Manusia Aparatur mempunyai tugas melakukan penyiapan bahan pelaksanaan pengembangan sumber daya manusia aparatur di bidang kompetensi pengembangan sumber daya manusia bidang kepemimpinan, manajemen, dan administrasi.

$$
\text { Pasal } 946
$$

Bidang Penyelenggaraan Pendidikan dan Pelatihan dan Pengelolaan Sarana Prasarana mempunyai tugas penyelenggaraan dan pemantauan pendidikan dan pelatihan serta pengelolaan sarana prasarana dan informasi pengembangan sumber daya manusia dan Informasi di bidang kepemimpinan, manajemen, dan administrasi.
MENJADI

Pasal 941

(1) Subbidang Program mempunyai tugas melakukan penyiapan bahan penyusunan pengelolaan rencana, program, anggaran, pelaporan, dan pelaksanaan kerja sama analisis kebutuhan pengembangan kompetensi sumber daya manusia bidang kepemimpinan, manajemen, dan administrasi.

(2) Subbidang Evaluasi mempunyai tugas melakukan penyiapan bahan evaluasi, dan akuntabilitas kinerja pengembangan sumber daya manusia bidang kepemimpinan, manajemen, dan administrasi.

Pasal 942

Bidang Penilaian Kompetensi Aparatur mempunyai tugas melaksanakan penyiapan, dan penyelenggaraan penilaian kompetensi sumber daya manusia aparatur

\section{Pasal 943}

Dalam melaksanakan tugas sebagaimana dimaksud dalam Pasa 942, Bidang Penilaian Kompetensi Aparatur menyelenggarakan fungsi:

a. penyiapan bahan penyusunaninstrumen penilaian kompetensi, pemetaan, dan penetapan asesi-dan

b. penyiapan bahan pelaksanaan penilaian kompetensi dan penyusunan rekomendasi tindak lanjut pengembangan kompetensi sumber daya manusia aparatur

\section{Pasal 944}

Bidang Penilaian Kompetensi Aparatur terdiri atas:

a. Subbidang Penyiapan Standar Penilaian Kompetensi Aparatur; dan

b. Subbidang Penyelenggaraan Penilaian Kompetensi Aparatur.

\section{Pasal 945}

(1) Subbidang Penyiapan Standar Penilaian KompetensiAparatur mempunyai tugas melaksanakan penyiapan bahan penyusunan instrumen penilaian kompetensi,pemetaan, dan penetapan asesi.

(2) Subbidang Penyelenggaraan Penilaian Kompetensi Aparatur mempunyai tugas melakukan penyiapan bahan pelaksanaan penilaian kompetensi dan penyusunan rekomendasi tindak lanjut pengembangan kompetensi sumber daya manusia aparatur.

\section{Pasal 946}

Bidang Penyelenggaraan Pengembangan Kompetensi Aparatur mempunyai tugas melaksanakan penyiapan penyusunan norma, standar, pedoman, dan kriteria serta penyelenggaraan, pemantauan, dan sistem informasi pengembangan kompetensi aparatur bidang kepemimpinan, manajemen, dan administrasi. 


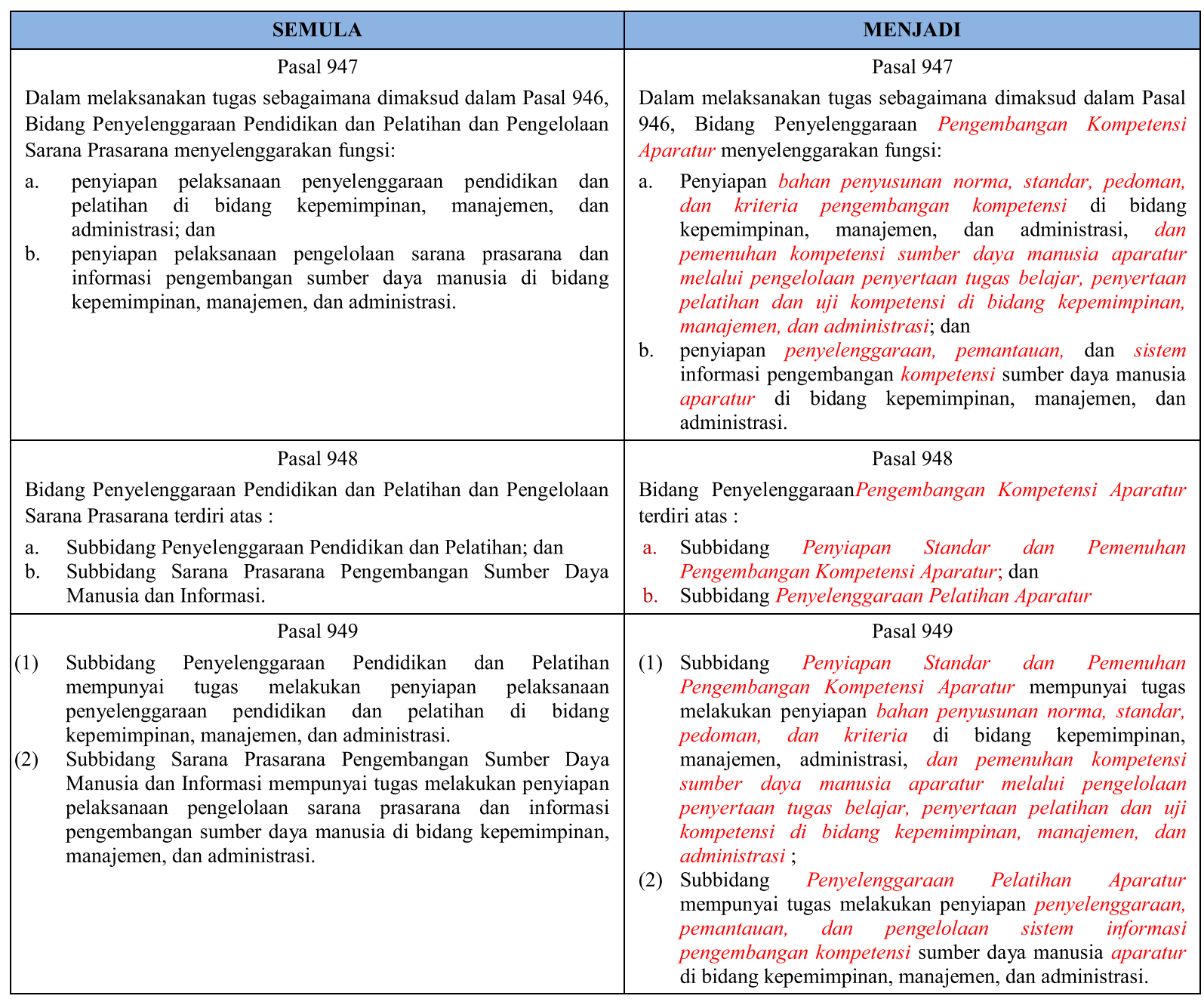

Berdasarkan uraian diatas, terdapat penambahan katauntuk fungsi dari PPSDM Aparatur, yaitu penambahan kata "kompetensi". Kata kompetensi tersebut sangat mempengaruhi dari fungsi keseluruhan dari PPSDM Aparatur. Fungsi dari PPSDM Aparatur bertambah berupa adanya fungsi Asessment Center. PPSDM Aparatur mempunyai tugas untuk melaksanakan penyiapan, dan penyelenggaraan penilaian kompetensi sumber daya manusia aparatur.

Perubahan pada Bidang Program dan Evaluasi terdapat penambahan tugas yakni pada Sub Bidang Program, yaitu melaksanakan analisis kebutuhan pengembangan kompetensi sumber daya manusia yang merupakan dasar atau pondasi dari program peningkatan kompetensi dari sumber daya manusia aparatur sehingga perencanaan peningkatan sumber daya manusia aparatur dapat sejalan dengan pelaksanaan peningkatan sumber daya manusia aparatur. Untuk Bidang Pengembangan Kompetensi Sumber Daya Manusia Aparatur, terdapat perubahan nomenklatur menjadi Bidang Penilaian Kompetensi Aparatur, dimana terdapat penambahan tugasnya yaitu melaksanakan penilaian kompetensi sumber daya manusia aparatur. Penambahan tersebut membuat dampak yang sangat signifikan terhadap pelaksanaan tugas bidang ini. Penambahan tugas ini termasuk untuk penyusunan instrumen penilaian kompetensi, pemetaan, dan penetapan asesi, penilaian kompetensi dan penyusunan rekomendasi tindak lanjut pengembangan kompetensi. Tugas-tugas tersebut termasuk dalam tugas dari Asessment Center. Usulan perubahan atau re-organisasi ini sebagai dasar dari pelaksanaan tugas Asessment Center dari PPSDM Aparatur yang belum diatur dalam Menteri Energi dan Sumber Daya Mineral Nomor 13 Tahun 2016. Disamping itu, Bidang Penyelenggaraan Pendidikan dan Pelatihan dan Pengelolaan Sarana Prasarana juga mengalami perubahan signifikan dan berdampak pada perubahan tugas dan fungsi. Fungsi bidang tersebut sebelumnya fokus pada pelaksanaan penyelengaraan pelatihan dan pada pengelolaan sarana dan prasarana serta informasi. Sebagai akibat dari reorganisasi, bidang ini berubah nomenklatur 
menjadi Bidang Penyelenggaraan Pengembangan Kompetensi Aparatur, dimana tugas dan fungsi yang baru disamping melaksanakan penyelenggaraan pelatihan, ditambah dengan penyusunan norma, standar, pedoman, dan kriteria.

Perubahan tugas dan fungsi diatas sangat berdampak bagi organisasi, dengan background pendidikan berdasarkan keilmuan di PPSDM Aparatur, jumlah Sarjana dan Pasca Sarjana Teknis sebanyak 23 (dua puluh tiga) orang, sedangkan yang berlatar belakang keilmuan non teknis sebanyak 29 (dua puluh sembilan) orang, sehingga perlu dilakukan penempatan kembali pegawai atau rotasi pegawai. Hal ini dapat dimulai dengan dibuat kembali (revisi) dari Analisa Jabatan dan Uraian Jabatan yang nantinya akan merubah keseluruhan Peta Jabatan yang menjadi dasar untuk penempatan pegawai. Reorganisasi ini perlu dilaksanakan agar supaya agar tidak terjadi ketimpangan dan ada pemerataan kemampuan pegawai.

\section{PENUTUP}

\section{Kesimpulan}

Organisasi publik bukanlah suatu sistem yang statis. Organisasi akan terus mengalami perubahan karena unsur-unsur yang membentuk organisasi tersebut juga ikut mengalami perubahan. Organisasi sering dipandang sebagai suatu organisme hidup yang kelangsungannya sangat tergantung dari lingkungannya.

PPSDMA merupakan organisasi dalam hal ini PPSDMA harus secara terus menerus menyesuaikan diri dengan berbagai perubahan lingkungan eksternal. Re-organisasi yang diajukan oleh PPSDMA adalah salah satu cara untuk beradaptasi dari perkembangan yang berlangsung saat ini. Bidang-bidang di PPSDMA mengalami perubahan tugas dan fungsi terutama di Bidang Program dan Evaluasi, Bidang Pengembangan Kompetensi Sumber Daya Manusia Aparatur, dan Bidang Penyelenggaraan Pendidikan dan Pelatihan dan Pengelolaan Sarana Prasarana. Perubahan di Bidang Program dan Evaluasi hanya menambahkan fungsi Analisis Kebutuhan pengembangan Kompetensi Sumber Daya Manusia Aparatur, untuk Bidang Pengembangan Kompetensi Aparatur terdapat penambahan tugas dan fungsi, yaitu dengan adanya Asessment Center di PPSDMA. Perubahan signifikan juga terdapat di Bidang Penyelenggaraan Pendidikan dan Pelatihan dan Pengelolaan Sarana Prasarana, dimana ada penambahan tugas dan fungsi yaitu penyusunan norma, standar, pedoman, dan kriteria.
Perubahan eksternal yang saat ini harus segera direspon adalah tuntutan akan demokratisasi, transparansi, dan akuntabilitas. Penataan organisasi membutuhkan persiapan yang matang serta harus dikomunikasikan secara berkelanjutan dengan pihak-pihak terkait sehingga gejolak dapat diminimalkan.

\section{Saran}

Untuk perubahan organisasi PPSDMA yang sudah diusulkan, diharapkan adanya rotasi pegawai supaya pemerataan dan tidak terjadi ketimpangan dalam pelaksanaan tugas dan fungsi pegawai. Rotasi ini dimulai dengan dibuatnya Analisa Jabatan dan Uraian jabatan oleh Sub Bagian Kepegawaian, dimana Analisa Jabatan dan Uraian Jabatan yang baru yang nantinya akan menjadi dasar Peta Jabatan yang akan digunakan untuk penempatan pegawai sehingga pegawai dapat bekerja secara maksimal.

\section{Daftar Pustaka}

Fathoni, Abdurrahmat, (2006), Organisasi dan Manajemen Sumber Daya Manusia, Jakarta, PT. Rineka Cipta

Hasibuan, Malayu SP, (2010), Organisasi dan Motivasi, Jakarta, PT. Bumi Aksara

Hayati, Tri. (2014), Bahan Perkuliahan Birokrasi dan Good Governance, Jakarta, Universitas Indonesia

Nugroho, Rian D, (2001), Reinventing Indonesia, Jakarta, Elex Media Komputindo

Said, M. Mas'ud, (2009), Birokrasi di Negara Birokratis, Makna, Masalah, dan Dekonstruksi Birokrasi Indonesia, Malang, UMM Press

Santosa, Pandji, (2008), Administrasi Publik; Teori dan Aplikasi Good Governance, Bandung, Refika Aditama

Sedarmayanti, (2009), Reformasi Administrasi Publik, eformasi Birokrasi dan Kepemimpinan Masa Depan, Mewujudkan Pelayanan Prima dan Kepemerintahan yang Baik, Bandung, Refika Aditama

Thoha, Miftah, (2007), Birokrasi dan Politik di Indonesia, Jakarta, PT. Raja Grafindo , (2008), Birokrasi Pemerintah di Era Reformasi, Jakarta, Kencana

Wibowo, (2011), Manajemen Perubahan, Ed. 3, Jakarta Rajawali Press 